\title{
Credit Risk Management Framework for Rural Commercial Banks in China
}

\author{
Yang Wang1, Wenchun Wang 1 , Jiaojiao Wang ${ }^{2}$ \\ ${ }^{1}$ Financial Research Center, Fudan University, Shanghai, China \\ ${ }^{2}$ School of Economics, Fudan University, Shanghai, China \\ Email: mialwngy@163.com, wangwc@fudan.edu.cn, 842031664@qq.com
}

How to cite this paper: Wang, Y., Wang, W. C., \& Wang, J. J. (2017). Credit Risk Management Framework for Rural Commercial Banks in China. Journal of Financial Risk Management, 6, 48-65. https://doi.org/10.4236/jfrm.2017.61005

Received: October 19, 2016

Accepted: March 7, 2017

Published: March 10, 2017

Copyright ( 92017 by authors and Scientific Research Publishing Inc. This work is licensed under the Creative Commons Attribution International License (CC BY 4.0).

http://creativecommons.org/licenses/by/4.0/

\section{(c) (i) Open Access}

\begin{abstract}
Credit risk management (CRM) is to identify, measure, monitor, and control risk arising from the possibility of default in payments. Existing CRM tools available for large financial institutions do not meet the requirements of rural commercial banks (RCBs) because their main customers are SMEs and farming households whose financial data and credit rating records are not available. RCBs in China also expose specific risks connected to rural commercial banking business and in particular farming-related loans and services. Adopting a qualitative analysis approach to identify key factors contributing to failures of RCBs' customers, we endeavour to develop a CRM framework for RCBs in China. The framework, which is based on the identification of business failures of RCBs' customers and factors contributing to failures of SMEs and farming households, incorporates financial and non-financial variables. Using nonfinancial variables along with financial variables as predictors of company failure significantly improves credit analysis quality and accuracy. Also, this study recognises guanxi ${ }^{1}$ as risk potentials and includes guanxi risks in the framework. This study has made contributions to the extant literature on CRM of banks in general and RCBs in particular.
\end{abstract}

\section{Keywords}

Credit risk Management, Rural Commercial Bank

\section{Introduction}

Credit risk is a major risk faced by financial institutions as it takes up to $60.0 \%$ of risks that banks normally face (McKinsey \& Company, 1997). CRM has long

${ }^{1}$ Guanxi describes the basic dynamic in personalized networks of influence (which can be best described as the relationships individuals cultivate with other individuals) and is a central idea in Chinese society. 
been the focus of governments, regulatory authorities and financial institutions as most major banking problems have been either explicitly or indirectly caused by weaknesses in CRM (Basel Committee on Banking Supervision, 2001). China's fast-growth economy has led to a remarkable development in its financial institutions. However, Chinese financial institutions have been facing huge credit risk exposure reflected in the high level of bad loan (China Rural Commercial Bank Market Report, 2010-2011).

In China, rural commercial banks (RCBs) were originally derived from rural credit co-operatives that specifically work for rural population with low income. China's RCBs were developed under the authorities' initiatives to provide financial services support to rural areas and Sannong (pinyin: sān nóng) related business. Sannong refers to agriculture, rural areas and peasants. China's RCBs are different from the majority of rural credit cooperatives in other countries whose business operation focused only on agriculture, rural areas and farmers. In the Chinese case, RCBs also serve SMEs as their key customers and provide them with lending service. There has been a significant increase in the number of RCBs in China since the beginning of this century and the number had reached 85 up to the end of 2010. At the end of 2010, the total assets of Chinese RCBs registered RMB2.8 trillion, the total liabilities RMB2.6 trillion and the after-tax profit RMB27.99 billion. Chinese RCBs took a rising proportion in banking financial institutions from $1.15 \%$ in 2006 to $2.90 \%$ in 2010 . At the end of 2010 , the non-performing loan ratio of Chinese RCBs turned out to be $2.34 \%$ and the balance of bad loans amounted to RMB28.82 billion, an increase of RMB1.71 billion from the beginning of 2010. RCBs became the sole category that featured the rising bad loan balance among various banks in China (China Rural Commercial Bank Market Report, 2010-2011). RCBs are exposed to risks inherent to specific rural commercial banking business and in particular, Sannong-related loans and services, in addition to usual risks faced by financial institutions. For many RCBs, their business focus is to provide high-quality financial services to SMEs in rural and county areas and serve the needs of Sannong. Consequently, RCBs had generally presented relatively higher risks than large city commercial banks, partially because their primary source of income is interest income and their ability to generate fee and commission income is limited.

At the moment, many RCBs adopt the traditional CRM approaches used by large commercial banks. It is questionable if these approaches would be effective in managing credit risks of RCBs that operate in a different business environment. Research in CRM of Chinese RCBs is in scarcity. This research attempts to develop a CRM framework for Chinese RCBs. The framework incorporates main factors that affect credit risk facing RCBs in relation to environmental, operational, financial and guanxi variables contributing to failures of SMEs and farming households, the main customers of RCBs in China. The framework outlines the procedure that RCBs can follow to develop its own credit risk analysis model in accordance with their portfolios of loans and the characteristics of their customers. 
This paper is organized as follows. The next section introduces China's banking reform and the development of China's RCBs. The third section provides a literature review on CRM. The fourth section analyses factors contributing to failures of SEMs and farming households and proposes a CRM framework for RCBs in China. The final section concludes the paper and highlights the limitations and future research directions.

\section{China's Banking Reform and Rural Commercial Banks}

\subsection{China's Banking Reform}

China's banking reform was carried out within the broader context of China's transition from a planned economy to a market economy. Prior to the beginning of the reform, China's banking system consisted of only one financial institution, the People's Bank of China ( $\mathrm{PBC}$ ). The "first stage" of the banking reform took root in the early 1980s by creating a two-tier bank system. The PBC became the central bank. The Industrial and Commercial Bank of China (ICBC) was carved out of the PBC and, together with the China Construction Bank (CCB), Bank of China (BOC) and the Agricultural Bank of China ( $A B C)$, the four so-called specialized banks became the second tier of the system. The Big Four banks were $100 \%$ state-owned. In the early stage of reform the specialized banks were allowed very little scope to extend commercial or consumer credit.

The second stage began in 1994 when the Big Four banks were relieved of their role in "policy lending"2. In 1995 the Commercial Bank Law of China was promulgated, recognising the status of state-owned specialised banks as commercial banks operating according to market based banking principles of capital-adequacy, prudence, profitability, risk recognition, liquidity and responsibility for own profit and loss. In 1997 the Central Committee of the Communist Party and the State Council held the first National Financial Operations Conference and introduced several important measures to accelerate the reforms. First, the government issued RMB270 billion (US\$33 billion) in special government bonds to recapitalise the Big Four banks. Second, new regulations abolished the credit quota policy (by which the commercial banks had quotas imposed on them concerning to whom and how much they could lend) and, instead, allowed banks to adopt asset-liability management. Finally, in a dramatic and significant step that marks the transition from the second to the third stage of banking reform, the central government transferred RMB1.4 trillion (US $\$ 170$ billion) in nonperforming loans from the books of the state-owned commercial

${ }^{2}$ The three policy banks cover the following parts: a) Agricultural Development Bank of China (ADBC) took over the policy lending role of the $\mathrm{ABC}$. ADBC provides loans for the purchase, transport, marketing and reserves of selected agricultural products (grain, oil, cotton, meat, sugar, tobacco and wool) and loans for enterprises involved in processing. It takes deposits from publicly-owned entities and manages their international transactions. b) China Development Bank (CDB) took over the policy lending role of the CCB and, to a lesser extent, the ICBC. The CDB is responsible for financing public-sector investment in support of national economic development and strategic structural readjustment. c) Export-Import Bank of China (EXIM) took over the policy-lending role from the BOC, especially the trade financing function and inter-bank transactions. EXIM provides guarantees and concessional loans for firms involved in international trade and investment. 
banks to new entities dubbed Asset Management Companies (AMCs) ${ }^{3}$.

The third stage of banking reform is to turn state-owned commercial banks into joint-stock commercial banks with the state as the controlling shareholder. In late 2003 the Law on the People's Bank of China and the Commercial Banking Law were amended to establish the China Banking Regulatory Commission (CBRC) to oversee the reform of regulation of banking. Changes to the Commercial Banking Law freed the Big Four from the requirement to provide loans to State Council-approved projects and permitted them to carry out commercial banking activities-such as trading government bonds, dealing in foreign exchange and offering credit card services.

As of end-2010, China's banking sector comprises of two policy banks and China Development Bank (CDB), five large commercial banks, 12 joint-stock commercial banks, 147 city commercial banks, 85 rural commercial banks, 223 rural cooperative banks, 2,646 rural credit cooperatives (RCCs), one postal savings bank, four banking assets management companies, 40 locally incorporated foreign banking institutions, 90 foreign bank branches, 63 trust companies, 107 finance companies of corporate groups, 17 financial leasing companies, four money brokerage firms, 13 auto financing companies, four consumer finance companies, 349 village or township banks, nine lending companies and 37 rural mutual cooperatives. In addition, a total of 395 new-type rural financial institutions were established, including 349 village or township banks, nine lending companies and 37 rural mutual cooperatives. The deposits attracted by these institutions totalled RMB75.27 billion, loans totaled RMB60.09 billion, and profits totaled RMB950 million. Meanwhile, 86.7 percent of the loans made by these institutions went to rural and agricultural uses as well as to SMEs. Among all, loans dispersed to SMEs alone numbered 31,000 and valued in aggregate RMB31.38 billion or 52.2 percent of the total value, while loans extended to rural households numbered 237,000 and valued RMB20.74 billion or 34.5 per cent of the total (CBRC, 2011).

\subsection{Microfinance and Rural Commercial Banks in China}

China as the largest country in terms of populations with around 26.88 million people living in poverty (China Financial Daily, 2011) needs to reduce the huge gap between the rich and the poor. The Chinese government realises the potential of microfinance in poverty alleviation and has actively promoted microfinance since 1993 (Rahman and Luo, 2011). In 2005, China established microcredit companies in Sichuan, Guizhou, Shaanxi and Inner Mongolia Provinces, continuing to enlarge microfinance market in China (He et al., 2009). China Association of Microfinance (CAM) was launched in 2005, which is a self-regulated association to uphold microfinance in China.

For many RCBs, their business objective is to provide high-quality financial services to customers in rural and county areas and serve the needs of Sannong.

${ }^{3}$ Four AMCs include Great Wall for the Agricultural Bank of China, Orient for the Bank of China, Huarong for the Industrial and Commercial Bank of China, and Cinda for the China Construction Bank. 
Chinese RCBs are largely formed under the government initiatives. The authorities require RCBs to allocate a certain percentage of newly issued loans to support the Sannong development each year. Consequently, RCBs very much expose banking risks associated with Sannong-related industries. Compared to the city-based large commercial banks in China, the products and services currently offered by RCBs are relatively simple. Customer deposits remain RCBs' primary funding source. RCBs rely heavily on deposit and loan business, and less on feeand commission-based business and investment. They also rely on favourable government policies and initiatives in respect of ${ }^{4}$ county area development and the Sannong reform. Internet banking is less developed in RCBs.

With regard to RCBs' lending activities, there are several characteristics: 1) loans are relatively small and generally unsecured; 2) loans are made normally to customers that have strong quanxi with the banks and local governments; 3 ) internal monitoring, political and social sanctions are often used to enforce RCB loan contracts. Although the cooperative nature of RCBs greatly reduces asymmetric information problems, due to low understanding of the operations of finance and lending system, the borrowers did not have much role to play in the process and risk management. Unlike larger lenders, it is very difficult for RCBs to diversify spatially. This leaves RCBs highly vulnerable to correlated risk exposure from events such as natural disasters.

RCBs' risk management capacity is inadequate. Most RCBs are lacking of comprehensive risk management concept, awareness and culture. Bank managers in RCBs tend to lay more attention on business development rather than internal control of the risk arising from the loan issuing. As a result of weakness in internal control, many RCBs suffered from internal control deficiencies and lapses in control processes. Due to limitations on the information, resources or tools available, RCBs are facing some difficulties to address the risks in their operations effectively or respond to sudden changes in business environments in a timely manner. RCBs have the highest percentage of NPLs in their total loan portfolios according to CBRC Annual Report (2010).

\section{Literature Review}

The following part provides a general description of the background of credit risk and common credit risk measurement approaches.

\subsection{Credit Risk}

Credit risk is generally defined as the potential that an institution borrower or counterparty will fail to meet its obligations in accordance with agreed terms. According to the Basel Committee on Banking Supervision (2001), the most common cause that leads the banks to bankruptcy is credit risk. The main

\footnotetext{
${ }^{4}$ Such policies and initiatives include, among others, providing public finance to support the county area development, introducing financial products such as business start-up loans to the Sannong-related businesses, developing insurance services in the county areas in China to manage risks from catastrophic events and health and safety accidents, as well as providing subsidies for purchasing electronic products, farm equipment, vehicles and construction materials.
} 
sources of credit risk that have been identified in the literature include, limited institutional capacity, inappropriate credit policies, volatile interest rates, poor management, inappropriate laws, low capital and liquidity levels, massive licensing of banks, poor loan underwriting, reckless lending, poor credit assessment, laxity in credit assessment, poor lending practices, government interference, inadequate supervision by the central bank, and information asymmetry (Stiglitz and Weiss, 1981; Chen et al., 2006; Ayayi, 2012).

To measure credit risk is the key to manage credit risks. The credit rating assessment becomes an important part of credit risk assessment, involving risk parameters such as financial, business, industry and management areas (Gama and Geraldes, 2012; Jin et al., 2012). In addition to measuring and controlling it, banks also try mitigating their credit risk. A variety of approaches can be adopted to mitigate its credit risks, including, among others, risk-based pricing, covenants, credit insurance, credit derivatives, collaterals, engaging in credit guarantee scheme.

Credit ratings provide an estimate of the creditworthiness of an entity, and are generally a reflection on an entity's ability to repay debt. In addition to the standard ratings provided by credit-rating agencies, firms often make use of internal ratings that they calculate themselves. Internal credit risk rating systems are becoming an increasingly important element of large commercial banks' measurement and management of the credit risk of both individual exposures and portfolios. Treacy and Carey (2000) explain the internal rating systems presently in use at the 50 largest US banking organizations. The authors use the diversity of current practice to illuminate the relationships between uses of ratings, different options for rating system design, and the effectiveness of internal rating systems and show that growing stresses on rating systems make an understanding of such relationships important for both banks and regulators. Medema et al. (2009) propose and implement a simple validation methodology that can be used by banks to validate their credit risk modelling exercise.

\subsection{Credit Scoring System}

Credit scoring systems can be found in virtually all kinds of credit analysis, ranging from individual consumer credit to giant commercial loans. The idea across different categories is literally the same: Pre-define certain key factors that determine probability of default (or repayment), and combine or weight them into a quantitative score. Beaver (1967) first utilises several financial ratios to investigate corporate default. The cut-off point of default companies and nondefault companies is derived out of the historic sample. Then the financial ratios are calculated to compare with the cut-off point in order to differentiate the corporate bankruptcy. Based on previous study, Altman (1968) constructs the classical Z-score model to predict the possibility that a firm will go bankruptcy. In this study, 22 variables were taken from the financial reports of a matched sample of 66 companies, divided into two groups, 33 each. The 22 variables were categorised into five explanatory indices by multiple discriminant analysis. The 
model assumes that the sample data are normally distributed and the covariance remains the same. The best fitting scoring model for commercial loans is a linear combination of five usual business ratios, weighted by estimated coefficients. A critical point was applied to determine the risk level of corporate loan in a certain period of time. The higher the score was, the "healthier" the company was. The option of the best critical might change due to economic conditions. When the economy is expected to go down, the critical point would be raised to compensate. This will reduce the model's Type 1 Error (lending to customers with bad credit), but lead to the increases of Type 2 Error (customers with good credit will be denied).

The above model has been amended and expanded over time and the ZETA model was developed later on (Altman et al., 1977). The major evolution of ZETA model from Z-score is that five variables are extended into seven. The ZETA model presents more precise result than its ancestor owing to improvement of the variables chosen and better stability of new variables. The Z-score model is widely adopted in the literature because it is straightforward to operate and simple to accommodate into different economic environments (Altman et al., 1979) ${ }^{5}$. For example, Pille and Paradi (2002) take the Z-score model in predicting the failure of Credit Unions in Ontario, Canada. Altman (2005) revises the Z-score model for emerging market corporate bonds rating in Mexico. Recently, the type of model has performed less well. Mester (1997) reports that 56 per cent of the 33 banks that used credit scoring as a way of approving credit card applications failed to predict loan quality problems.

\subsection{Equations}

The equations are an exception to the prescribed specifications of this template. You will need to determine whether or not your equation should be typed using either the Times New Roman or the Symbol font (please no other font). Equations should be edited by Mathtype, not in text or graphic versions. You are suggested to use Mathtype 6.0 (or above version).

Number equations consecutively. Equation numbers, within parentheses, are to position flush right, as in (1), using a right tab stop. To make your equations more compact, you may use the solidus (/), the exp function, or appropriate exponents. Italicize Roman symbols for quantities and variables, and Greek symbols. Do not italicize constants as $\pi$, etc. Use a long dash rather than a hyphen for a minus sign. Punctuate equations with commas or periods when they are part of a sentence, as in

$$
\alpha+\beta=x
$$

Note that the equation is centered. Be sure that the symbols in your equation have been defined before or immediately following the equation. Use "Equation

\footnotetext{
${ }^{5}$ However, there are certain defects of Z-score model. First, the model assumes that the explanatory factors are linear while in the real business world, an amount of firm defaults is not following the same path. Second, both Z-score and ZETA models rely on accounting data fetched from financial reports. In most countries, accounting ratios are recorded at discrete intervals and based on book value principles and both models cannot calculate off-balance sheet credit risk.
} 
(1)", not "Equation (1)" or "(1)", and at the beginning of a sentence: "Equation (1) is ..."

\subsection{Default Models}

Default models include credit metrics, credit risk plus, KMV and credit portfolio models. Default models differ from credit scoring models in two ways: Credit scoring is usually applied to smaller credits-individuals or small businesses. Default models are applied more to larger credits. Traditional methods of credit risk measurement focus on estimating the probability of default, rather than on the magnitude of potential losses in the event of default. Moreover, traditional models typically specify "failure" to be bankruptcy filing, default, or liquidation, thereby ignoring consideration of the downgrades and upgrades in credit quality that are measured in mark to market models.

Empirical evidence suggests that default severities and recoveries are quite volatile over time (Altman et al, 1977; Crouhy et al., 2000; Jacobs, 2012). A recent study by Alessandri and Drehmann (2010) develops an economic capital model integrating credit and interest rate risk and argues that banks often measure credit and interest rate risk in the banking book separately and then add the risk measures to determine economic capital. Breuer et al. (2010) also note such problem in their study, observing that there is a tradition in the banking industry of dividing risk into market risk and credit risk. Both categories are treated independently in the calculation of risk capital. But many financial positions depend simultaneously on both market risk and credit risk factors. In this case, an approximation of the portfolio value function separating value changes into a pure market risk plus pure credit risk component can result not only in an overestimation, but also in an underestimation of risk.

\subsection{Approaches to Credit Risk Models}

Building credit risk models as the basis for evaluating default exposures remains a fundamental issue. The seminal works by Beaver (1967) and Altman (1968) develop univariate and multivariate models to predict business failures using a set of financial ratios. Beaver (1967) uses a dichotomous classification test to determine the error rates that a potential creditor would experience if it classified firms on the basis of individual financial ratios as failed or non-failed. He uses a matched sample consisting of 158 firms (79 failed and 79 non-failed) and analyses 14 financial ratios. Altman (1968) uses a multiple discriminant analysis (MDA) technique to solve the ambiguity problem linked to Beaver's univariate analysis and to assess a more complete financial profile of firms. The analysis draws on a matched sample containing 66 manufacturing firms (33 failed and 33 non-failed) that filed a bankruptcy petition during the period 1946-65. Altman examines 22 potentially helpful financial ratios and selects five that provide, when combined, the best overall prediction of corporate bankruptcy. The variables are classified into five standard ratio categories: liquidity, profitability, leverage, solvency, and activity ratios. 
The literature on the modelling of credit risk for large, listed companies is extensive and gravitates toward either of two approaches: the $\mathrm{Z}$ score approach of using historical accounting data to predict insolvency (e.g., Altman, 1968); and models that rely on securities market information (e.g., Merton, 1974). In city commercial banks, risk modelling can be undertaken using very large samples of high-frequency corporate data and combinations of in-house portfolio data (e.g., payment history) and data from the credit reference agencies to develop proprietary models. Due to a lack of data, modelling approaches have limited applicability to RCBs where credit risk is managed mainly on an ad hoc basis.

\section{Research Methods}

RCBs' clients are a distinct kind of client with specific needs and peculiarities that require risk-management tools and methodologies specifically developed for them. The problem of obtaining accurate information about the health of SMEs, while not new, is particularly relevant for patterning firms' bankruptcy or default. In the past decades, considerable research (see, e.g., Phillips and Kirchhoff, 1989; Watson and Everett, 1993; Everett and Watson, 1998; Headd, 2003) has been conducted to determine the rates and causation of such default. Early research into corporate bankruptcy prediction involved determining which accounting ratios best predict failure, primarily employing multiple discriminant analysis (MDA) or logit/probit models. In most of these accounting ratio-based studies, ratios are calculated at a predetermined time before bankruptcy (usually one year) and as such these models are often referred to as static models. For example, Altman and Sabato (2007) apply a distress prediction model estimated specifically for the US SMEs based on a set of financial ratios derived from accounting data. They demonstrate that banks should not only apply different procedures (in the application and behavioural process) to manage SME clients as compared with large corporate firms, but these organisations should also use scoring and rating systems specifically addressed to the SME portfolio. Other studies focus on the use of data other than accounting data. For example, von Stein and Ziegler (1984) examine the impact of managerial behaviour on failure.

The literature has predominantly adopted quantitative approach in CRM research. The quantitative research usually concentrates on measurements and numbers with a view to finding out the association between variables. A number of methods have been used to develop CRM models, including, for example, discriminant function analysis, regression analysis, principal component analysis and factor analysis.

A qualitative research approach was chosen for this study because of its greater exploratory nature and therefore its applicability to this research domain as it focuses on gaining a general understanding of the subject area at an earlier stage. This was vital in light of this study because there is very little research conducted on CRM of RCBs in China. Also, as RCBs began very recently in China, quantitative data and credit risk information are not readily available. Moreover, the customers of RCBs are mainly SMEs and farming households with limited in- 
formation available on their business failures. Qualitative assessment of credit risk has been suggested in the literature (Ribeiro et al., 2011).

The research also uses the case study approach to investigate the CRM issues faced by RCBs. The case study is to provide empirical evidence through interviews to support the argument of this study and to gain perceptions of key players with regard to the appropriateness of the proposed model. The literature has well documented the advantages and limitations of case study approach and their applying conditions (Yin, 1994). Single case studies have been justified as an appropriate method for theory development (Eisenhardt, 1989; Stuart et al., 2002). The case study of a RCB was screened initially through eight face-to-face interviews conducted in August 2010, and then subsequent e-mail and telephone conversations. The case is a local RCB located in Jiangsu province, in the eastern part of China where SMEs were well developed. This case bank is one of the early developed RCBs in China and has developed a relatively comprehensive CRM system. Information-gathering techniques implemented during execution of the case study included obtaining historical data and documentation, as well as conducting semi-structured interviews with CRM personnel and bank managers in the case bank. Each interview has duration of approximately one hour and conducted in Chinese in the bank offices. The semi-structured interviews ensured that the researchers maintained control over each interview, without discouraging the discussion of any valuable, additional information. The information from the case and transcripts of interviews were analysed to identify risk factors facing SMEs and farming households.

\section{A Credit Risk Management Framework}

The focus of CRM for RCBs is to analyse failures of RCBs' customers (i.e., SMEs and farming households). It is extremely important to distinguish between failures and closures. Watson and Everett (1996) note that closing firms could have been financially successful but closed for other reasons. To define failures they create five categories: ceasing to exist (discontinuance for any reason); closing, or a change in ownership; filing for bankruptcy; closing to limit losses; and failing to reach financial goals. Headd (2003) finds that only one-third of new businesses closed under circumstances that owners considered unsuccessful.

In the proposed framework, it is essential for RCBs to carry out this kind of analysis before starting to develop a default prediction model concerning their SME and farming household clients. Separating the cases of closures from the ones of failures improves the quality of the available information and of the prediction power of a model. In the credit analysis, RCBs should take into account only clients that entered into liquidation, administration or receivership.

The construction of CRM framework for RCBs should be based on the analysis of various risk factors affecting failures of the major customers of RCBs. In this study these risk factors are categorised into four clusters: environmental, financial, operational, and guanxi risks. These factors reflect the perceptions of various stakeholders involved in RCBs' CRM obtained through the case study. 
Different from the previous literature, this study considers both financial data and non-financial data in analysing credit risk. The value of non-financial information in SMEs' CRM has been recognised in the literature. The literature (e.g. Lehmann, 2003; Grunert et al., 2004; Altman et al., 2010) recognises that quantitative variables are not sufficient to predict SME default and qualitative variables (e.g., the number of employees, the legal form of the business, the region where the main business is carried out, the industry type, etc.) should be considered along with quantitative variables in predicting the failures of SMEs..

The framework is divided into five steps. The first step is to distinguish business failure and closure. In credit risk analysis, the focus should be on the failure. Business closure does not mean the failure. The second step is to identify factors contributing to the failure, which should be considered from environmental, operational, financial, and guanxi dimensions. Some factors may appear in one case, but not in other cases. The third step is to identify the principal factors by using specific techniques (such as principal components analysis). Based on the key factors, RCBs design credit risk analysis models with a focus on the analysis of these key/principal factors (step four). The final step is to use the credit risk analysis model to manage credit risks of their portfolios and individual loans.

\subsection{Environmental Risk}

SMEs and farming firms are facing the challenges raised from globalisation, increased customer expectations, technological advances, and increased competition. The main external environmental triggers include among others government laws and regulations, globalisation of markets and the internationalisation of business, major economic, political and social events, technological advancements, customer expectations, supplier requirements, increasing competition, organisational growth, and fluctuations in business cycles. The changing demographics (e.g., due to the consequence of China's one-child family policy) and the challenges to SMEs in attracting and retaining skilled workers were also identified as major factors influencing business failures. The recruitment and retention challenge is complex for SMEs and it is expected to continue over the long term. Demographic changes (e.g., only child in a family and young adults emigration), specifically the aging workforce and the declining entrant pool, are occurring in China and SMEs are currently countering some of the impacts.

A lack of effective risk management programme in SMEs is also a major factor contributing to the failure of many SMEs. One overriding factor that contributes to ineffective risk management in SMEs is a lack of infrastructure, risk management skills, human capital and adequate management knowledge and training (Alquier and Tignol, 2006). Gao et al. (2012) acknowledge the limited risk management capability building in Chinese SMEs largely due to lack of adequate education and qualification, higher staff turnover and negative attitudes of both owner-managers and employees towards the use of technology, learning and training. 


\subsection{Operational Risk}

Operational risk of SMEs and farming households is one of the major risk clusters to be considered for RCBs with regard to assessing credit risk of their loan portfolio. Due to the nature of SMEs and lacking of data, SME failure rates are very often difficult to track properly. Two of the main reasons businesses suffer unexpected closures are identified as insufficient capitalisation and lack of planning. When RCBs consider a SME for a load, they promptly look at all the planning documents and financial models applicable to the firm. Usually, the bank requires three years of taxes, current proof of any income, a financial statement and, if the company is already operating, financials for the company for at least two years. As such, banks take into account only a snapshot of the firm's current financial status and performance but do not consider the ability of the applicant to bring the loan to maturity, which depends on a number of non-financial factors and future development of the economy (both international/national and local/regional).

The age of the firm is also a factor to be considered as newly established firms are likely to be less stress in the earlier stage of the business development. Hudson (1987) suggests that a newly formed company is most likely to have a "honeymoon period" before being at real risk of failure as it takes time to build up problems and for creditors to get organized into formal insolvency proceedings. His finding suggests that young companies form the majority of the liquidated companies and that a company needs at least nine years to be regarded as established (i.e., lower the default risk of a start-up). However, he also finds evidence that a newly formed company is most likely to have a "honeymoon period" of around two years.

SMEs often rely heavily on trade finance from suppliers when bank finance is not available to them. Moreover, small companies extend trade credit to customers as a means of gaining and retaining customers. The use and extension of trade credit makes the business vulnerable to cash flow difficulties.

A potentially powerful addition to operational risks is the occurrence of "event" data, such as evidence of a company defaulting on credit agreements and/or trade credit payments or variables representing operational risk, and regulatory compliance, such as whether the firm is late to file its financial statements. CEOs who have personal affairs and family problems also considerably affect the normal operations of a business. Some of these "default events" are available from local government agencies and media. They should be used to adjust risk scores more frequently than is possible with annual accounting data. The number of court cases against the firm is also a key indicator of potential failures. For example, a county economic court judgment (CECJ), which arises from a claim made to the court following the non-payment of unsecured debt can be a potential factor. The accumulation of CECJs and/or CECJs against companies that are already showing signs of financial distress is likely to be an effective predictor of insolvency. 


\subsection{Financial Risk}

In the financial variables, our variable selection reflects the importance of working capital for the survival of SMEs firms and farming households. The literature on trade credit suggests that smaller firms both extend more credit to customers and take extended credit from suppliers when facing decline and financial stress. Trade credit forms a large proportion of a firm's liabilities, especially for small firms (Hudson, 1986).

In the analysis model, the accounting-based variables are used as one cluster of principal components to predict which firms will become insolvent and go into bankruptcy procedures. Return on Capital Employed (ROCE) was widely used as an indicator of performance in large firms. Frecknall-Hughes et al. (2007) note that ROCE is a particularly poor indicator of performance in SMEs and may be defined in many different ways giving rise to widely differing values of ROCE. Working capital is one of the most important variables in this cluster. A number of variables reflect a firm's working capital. The quick assets/current assets variable determines the extent to which current assets consist of liquid assets. The cash/total assets variable expresses cash as a proportion of total assets. The net cash/net worth variable measures net cash as a proportion of net worth. Other variables reflecting the working capital cycle are total liabilities/quick assets, trade debtors/total assets, trade creditors/trade debtors, trade creditors/total liabilities and inventories/working capital. Retained profit/total assets is a measure of the cumulative profitability of the firm, its leverage and the age of the company. Firms that are unable to accumulate profit from sales will have lower values of this variable. Short-term debt/net worth measures the changes in net worth and retained profit/total assets year on year. Financially distressed firms are more likely to have a declining and/or negative net worth. The inclusion of these variables allows us to control for both the level and the direction of net worth and profit. Apparently, there is a large degree of overlap between the operational and financial risks of a firm being captured by some of these variables.

\subsection{Guanxi}

In this proposed framework, guanxi is included as a major cluster of factors in credit analysis. Guanxi is an indigenous Chinese construct describing an informal connection between two or more individuals or groups involving shared social experience, the exchange of favours and trust (Lou, 1997; Wei et al., 2010). Guanxi has dominated all business and social activities that occur throughout China (Lovett et al., 1999; Taormina and Gao, 2010; Wei et al., 2010). For more than 2,500 years-since the time of Confucius-guanxi has been critically important to Chinese society.

Modern Chinese societies remain very much guanxi-oriented (Chen and Chen, 2004) and business operations and success in China are largely dependent on guanxi since it provides assurance of success in business operations (Seligman, 1999). Seligman (1999) finds that one of the few rules in China that leads to business success is the establishment of the right guanxi. Advantage in guanxi 
networks can lead an individual or organization to succeed (Islam and Kantor, 2005). This is ever more the case for SMEs and farming households.

Guanxi variables can be represented in a number of relations, including: government relations, community relations, customer relations, industrial relations, supplier relations, relations with the Chinese communist party (CPC), relations with the local trade association and professional bodies, and the social relations of individual employees with the society in general. Strong relations with these stakeholders provide a potential for business to win contract, gain favourable treatments and receive supports from them once the firm has difficulty. In consequence, firms with strong relations with these stakeholders are less likely to be failure comparing with firms with no relations or weak-relations with these stakeholders. In the analysis, it should be aware of that in the case of China, quite often the owners of SMEs and township firms when they do well in their firm are asked to take a government official job (i.e., promotion), which can lead to the closure of a business. It is well known that people with strong guanxi with governmental officials have a better chance to get promoted, develop business and win contracts. In the case interviews, several interviewees indicated the importance of Guanxi in predicting the failure of SMEs.

\section{Conclusion}

In practice, the building of credit risk models for SMEs and farming households and their lending portfolios is limited by data availability. Most Chinese SMEs are not required to disclose cash flow information that is very important for the classification of failed and non-failed firms. Existing CRM tools available for large financial institutions do not meet the requirements of RCBs because their main customers are SMEs and farming households and there is a lack of financial data and credit rating relating to these customers. RCBs in China also expose specific risks connected to rural commercial banking business and in particular, farming-related loans and services.

We adopt a qualitative analysis approach to identify key factors contributing to the failure of RCBs' customers and develop a CRM framework for RCBs in China. The framework is based on the identification of business failures of RCBs' customers and factors contributing the failures of SMEs and farming households. The framework embraces both financial and non-financial variables as using nonfinancial variables along with financial variables as predictors of company failure significantly improves credit analysis quality and accuracy. Also, this study recognizes guanxi as risk potentials affecting the business of SMEs and farming households and includes guanxi risks in the framework.

To the best of our knowledge, no study has specifically focused on CRM of China's RCBs. Thus, this study has contributed to the growing body of literature that studies CRM in financial institutions in general, and RCBs in particular. Firstly, this study critically identifies the current lack of studies specifically addressing RCBs and their CRM. It argues that the current prevailing CRM models that are based on large financial institutions have limited applicability to RCBs 
whose customers are mostly SMEs and farming households with poor or no credit record and information. Secondly, this study proposes a CRM framework for RCBs. Solutions to address RCBs' CRM have scarcely been provided in the existing literature. Our framework is the first of its kind in endeavouring to explore a solution to CRM of RCBs in China. Thirdly, this study recognizes guanxi as risk potentials includes guanxi risks in the framework. Using variables in guanxi as indicators of business failures bring in an additional dimension to credit risk analysis.

Like other research, this study is also subject to a number of limitations and there is much scope for further research. For example, this study has adopted qualitative approaches. The typical limitations of qualitative approaches remain. Given the lack of available data, this study focuses on the development of CRM framework, instead of designing credit analysis models. The application of the framework is largely subject to a number of practicalities which are not discussed in details in this study. Future research should pay more attention to those practicalities and address the difficulties in applying the framework. Also, this proposed CRM framework for ECBs remains to be validated. Different contexts may pose additional factors, even risk dimensions. Further research needs to add more empirical evidence from RCBs. Moreover, a potential area for further research may be a comparison of status quo of CRM between RCBs and city commercial banks over a longer period of time and between RCBs in China and other countries. This form of research may produce interesting findings in relation to the uniqueness of CRM of RCBs and its development over time.

In conclusion, $\mathrm{RCBs}$ operate in a different business environment and expose some unique risks, which require adopting a different CRM approach to incorporate environmental, operational, financial, and guanxi risks faced by RCBs' customers.

\section{References}

Alessandri, P., \& Drehmann, M. (2010). An Economic Capital Model Integrating Credit and Interest Rate Risk in Banking Book. Journal of Banking \& Finance, 34, 730-742. https://doi.org/10.1016/j.jbankfin.2009.06.012

Alquier, A. M. B., \& Tignol, M. H. L. (2006). Risk Management in Small- and Medium-Sized Enterprises. Production Planning \& Control: The Management of Operations, 17, 273-282. https://doi.org/10.1080/09537280500285334

Altman, E. I. (1968). Financial Rations, Discriminant Analysis and the Prediction of Corporate Bankruptcy. Journal of Finance, 23, 589-609. https://doi.org/10.1111/j.1540-6261.1968.tb00843.x

Altman, E. I. (2005). An Emerging Market Credit Scoring System for Corporate Bonds. Emerging Markets Review, 6, 311-323. https://doi.org/10.1016/j.ememar.2005.09.007

Altman, E. I., \& Sabato, G. (2007). Modelling Credit Risk from SMEs: Evidence from the US Market. Abacus, 43, 332-357. https://doi.org/10.1111/j.1467-6281.2007.00234.x

Altman, E. I., Baidya, T. K. N., \& Dias, L. M. R. (1979). Assessing Potential Financial Problems for Firms in Brazil. Journal of International Business Studies, 10, 9-24. https://doi.org/10.1057/palgrave.jibs.8490787

Altman, E. I., Haldeman, R. G., \& Narayanan, P. (1977). ZETA Analysis: A New Model to 
Identify Bankruptcy Risk of Corporations. Journal of Banking and Finance, 1, 29-54. https://doi.org/10.1016/0378-4266(77)90017-6

Altman, E. I., Sabato, G., \& Wilson, N. (2010). The Value of Non-Financial Information in Small and Medium-Sized Enterprise Risk Management. The Journal of Credit Risk, 6, 1-33. https://doi.org/10.21314/JCR.2010.110

Ayayi, A. G. (2012). Credit Risk Assessment in the Microfinance Industry. Economics of Transition, 20, 37-72. https://doi.org/10.1111/j.1468-0351.2011.00429.x

Basel Committee on Banking Supervision (2001). The Standardized Approach to Credit Risk, Consultative. Basel Committee on Banking Supervision.

Beaver, W. (1967). Financial Ratio as Predictors of Failure, Empirical Research in Accounting: Selected Studies 1966. Journal of Accounting Research, 4, 71-111. https://doi.org/10.2307/2490171

Breuer, T., Jandacka, M., Rheinberger, K., \& Summer, M. (2010). Does Adding up of Economic Capital for Market-and Credit Risk Amount to Conservative Risk Assessment, Journal of Banking \& Finance, 34, 703-712. https://doi.org/10.1016/j.jbankfin.2009.03.013

CBRC (China Banking Regulatory Commission) (2011). CBRC Annual Report 2010. Beijing: CBRC.

Chen, R.-R., Fabozzi, F. J., Pan, G. G., \& Sverdlove, R. (2006). Sources of Credit Risk: Evidence from Credit Default Swaps. The Journal of Fixed Income, 16, 7-21. https://doi.org/10.3905/jfi.2006.670090

Chen, X. P., \& Chen, C. C. (2004). On the Intricacies of the Chinese Guanxi: A Process Model of Guanxi Development. Asia Pacific Journal of Management, 21, 305-324. https://doi.org/10.1023/B:APJM.0000036465.19102.d5

China Rural Commercial Bank Market Report (2010-2011). http://www.researchinchina.com/Htmls/Report/2011/6137.html

Crouhy, M., Galai, D., \& Mark, R. (2000). A Comparative Analysis of Current Credit Risk Models. Journal of Banking \& Finance, 24, 59-117. https://doi.org/10.1016/S0378-4266(99)00053-9

Eisenhardt, K. M. (1989). Building Theories from Case Study Research. Academy of Management Review, 14, 532-550.

Everett, J., \& Watson, J. (1998). Small Business Failure and External Risk Factors. Small Business Economics, 11, 371-390. https://doi.org/10.1023/A:1008065527282

Frecknall-Hughes, J., Simpson, M., \& Padmore, J. (2007). Inherent Limitations in Using Financial Ratio Analysis to Assess Small and Medium Sized Company Performance. Working Paper.

https://www.researchgate.net/publication/228484206_Inherent_limitations_in_using_fi nancial_ratio_analysis_to_assess_small_and_medium_sized_company_performance

Gama, A. P. M., \& Geraldes, H. S. A. (2012). Credit Risk Assessment and the Impact of the New Basel Capital Accord on Small and Medium-Sized Enterprises: An Empirical Analysis. Management Research Review, 35, 727-749. https://doi.org/10.1108/01409171211247712

Gao, S., Sung, M. C., \& Zhang, J. (2012). Risk Management Capability Building in SMEs: A Social Capital Perspective. International Small Business Journal, 31, 677-700. https://doi.org/10.1177/0266242611431094

Grunert, J., Norden, L., \& Weber, M. (2004). The Role of Non-Financial Factors in Internal Credit Ratings. Journal of Banking and Finance, 29, 509-531.

https://doi.org/10.1016/j.jbankfin.2004.05.017 
He, G., Du, X., Bai, C., \& Li, Z. (2009). China Microfinance Industry Assessment Report. China Association of Microfinance.

Headd, B. (2003). Redefining Business Success: Distinguishing between Closure and Failure. Small Business Economics, 21, 51-61. https://doi.org/10.1023/A:1024433630958

Hudson, J. (1986). An Analysis of Company Liquidations. Applied Economics, 18, 219235. https://doi.org/10.1080/00036848600000025

Hudson, J. (1987). The Age, Regional and Industrial Structure of Company Liquidations. Journal of Business Finance \& Accounting, 14, 199-213. https://doi.org/10.1111/j.1468-5957.1987.tb00539.x

Islam, M., \& Kantor, J. (2005). The Development of Quality Management Accounting Practices in China. Managerial Auditing Journal, 20, 707-724. https://doi.org/10.1108/02686900510611249

Jacobs, M. (2012). An Empirical Study of the Returns on Defaulted Debt. Applied Financial Economics, 22, 563-579. https://doi.org/10.1080/09603107.2011.619495

Jin, J., Yu, Z., \& Mi, C. (2012). Commercial Bank Credit Risk Management Based on Grey Incidence Analysis. Grey Systems: Theory and Application, 2, 385-394. https://doi.org/10.1108/20439371211273267

Lehmann, B. (2003). Is It Worth the While? The Relevance of Qualitative Information in Credit Rating. http://ssrn.com/abstract $=410186$ https://doi.org/10.2139/ssrn.410186

Lou, Y. (1997). Guanxi and Performance of Foreign-Invested Enterprises in China: An Empirical Inquiry. Management International Review, 37, 51-70.

Lovett, S., Simmons, L. C., \& Kali, R. (1999). Guanxi versus the Market: Ethics and Efficiency. Journal of International Business Studies, 30, 231-247.

https://doi.org/10.1057/palgrave.jibs.8490068

McKinsey \& Company (1997). Credit Portfolio View. New York: McKinsey Inc.

Medema, L., Koning, R. H., \& Lensink, R. (2009). A Practical Approach to Validating a PD Model. Journal of Banking \& Finance, 33, 701-708. https://doi.org/10.1016/j.jbankfin.2008.11.007

Merton, R. C. (1974). On the Pricing of Corporate Debt: The Risk Structure of Interest Rates. Journal of Finance, 29, 449-470. https://doi.org/10.1111/j.1540-6261.1974.tb03058.x

Mester, L. (1997). What's the Point of Credit Scoring? Federal Reserve Bank of Philadelphia Business Review, 3-16.

Phillips, B., \& Kirchhoff, B. (1989). Formation, Growth and survival: Small Firm Dynamics in the US Economy. Small Business Economics, 1, 65-74. https://doi.org/10.1007/BF00389917

Pille, P., \& Paradi, J. C. (2002). Financial Performance Analysis of Ontario (Canada) Credit Unions: An Application of DEA in the Regulatory Environment. European Journal of Operating Research, 139, 339-350. https://doi.org/10.1016/S0377-2217(01)00359-9

Rahman, M. W., \& Luo, J. C. (2011). Sustainability of NGO-Type Microfinance Service Provider in Shaanxi, China: Peer with Grameen Bank, Bangladesh. African Journal of Business Management, 6, 5319-5327.

Ribeiro, M. S., Pina, J. P., Soares, J., \& Lopes, M. C. (2011). Quantitative vs. Qualitative Criteria for Credit Risk Assessment. Frontiers in Finance and Economics, 8, 69-87. https://doi.org/10.2139/ssrn.2012443

Seligman, S. D. (1999). Guanxi: Grease for the Wheels of China. The China Business Review, 26, 34-38. 
Stiglitz, J. E., \& Weiss, A. (1981). Credit Rationing in Markets with Imperfect Information. The American Economic Review, 71, 393-410.

Stuart, F. I., McCutcheon, D. M., Handfield, R. B., McLachlin, R., \& Samson, D. (2002). Effective Case Research in Operations Management: A Process Perspective. Journal of Operations Management, 20, 419-433. https://doi.org/10.1016/S0272-6963(02)00022-0

Taormina, R. J., \& Gao, J. H. (2010). A Research Model for Guanxi Behavior: Antecedents, Measures, and Outcomes of Chinese Social Networking. Social Science Research, 39, 1195-1212. https://doi.org/10.1016/j.ssresearch.2010.07.003

Treacy, W. F., \& Carey, M. S. (2000). Credit Risk Rating Systems at Large US Banks. Journal of Banking \& Finance, 24, 167-201. https://doi.org/10.1016/S0378-4266(99)00056-4

Von Stein, J. H., \& Ziegler, W. (1984). The Prognosis and Surveillance of Risks from Commercial Credit Borrowers. Journal of Banking \& Finance, 8, 249-268. https://doi.org/10.1016/0378-4266(84)90006-2

Watson, J., \& Everett, J. (1993). Defining Small Business Failure. International Small Business Journal, 11, 35-48. https://doi.org/10.1177/026624269301100302

Wei, L. Q., Liu, J., Chen, Y. Y., \& Wu, L. Z. (2010). Political Skill, Supervisor-Subordinate Guanxi and Career Prospects in Chinese Firms. Journal of Management Studies, 47, 437-454. https://doi.org/10.1111/j.1467-6486.2009.00871.x

Yin, R. K. (1994). Case Study Research: Design and Methods (2nd ed.). Thousand Oaks, CA: Sage.

\section{Submit or recommend next manuscript to SCIRP and we will provide best service for you:}

Accepting pre-submission inquiries through Email, Facebook, LinkedIn, Twitter, etc. A wide selection of journals (inclusive of 9 subjects, more than 200 journals)

Providing 24-hour high-quality service

User-friendly online submission system

Fair and swift peer-review system

Efficient typesetting and proofreading procedure

Display of the result of downloads and visits, as well as the number of cited articles

Maximum dissemination of your research work

Submit your manuscript at: http://papersubmission.scirp.org/

Or contact jfrm@scirp.org 